\title{
Pengembangan model pembelajaran sains kontekstual untuk peserta didik difabel netra
}

\author{
W. Winarti \\ ${ }^{1}$ Prodi Pendidikan Fisika, UIN Sunan Kalijaga, Yogyakarta, 55281, Indonesia \\ E-mail: winarti@uin-suka.ac.id
}

Received: 0307 2018. Revised: 2908 2018. Accepted: 21092018

\begin{abstract}
Abstrak
Penelitian ini bertujuan untuk mengembangkan sebuah model pembelajaran sains berbasis kontekstual untuk peserta didik difabel netra dalam setting sekolah inklusi. Model yang dikembangkan ini menjadi sangat penting untuk memfasilitasi kelamahan pembelajaran fisika selama ini untuk peserta didik difabel netra. Penelitian ini merupakan penelitian pengembangan (Research and Development) yang mengacu pada langkah pengembangan dari Borg \& Gall. Dari sepuluh langkah penelitian pengembangan Borg \& Gall, pada penelitian ini dibatasi pada tahap validasi. Hasil penelitian ini menunjukkan bahwa telah berhasil dikembangkan model pembelajaran sains kontekstual untuk peserta didik difabel netra dengan nama Model pembelajaran Art of Contextual Learning for Disability (A-CLeD). Model A-CLeD ini memiliki sintak yaitu; (1) Orientasi, (2) Korelasi, (3) Transformasi, (4) Mediasi dan (5) Refleksi. Hasil validasi isi (content validity) terhadap model ini menunjukkan kesimpulan bahwa model ini berkategori baik dan dapat digunakan dalam pembelajaran fisika untuk peserta didik difabel netra.
\end{abstract}

Kata Kunci: pembelajaran sains kontekstual; Difabel Netra; Art of Contextual Learning for Disability (A-CLeD)

\section{Development of contextual science learning model for blind student}

This study aims to develop a contextual science learning model for students with disabilities in the setting of inclusive schools. This developed model is very important to facilitate students with disabilities learn. This research is a development research (Research and Development. According to Borg \& Gall, research and development is a process used to develop or validate the products that are used in education and learning. A step-by-step method using the Research and Development $(R \& D)$ by Borg \& Gall. From the ten steps of Borg \& Gall's development research, this research is limited to the validation phase. The results of this study indicate that a contextual science learning model has been developed for students with visual disabilities with the name of the Art of Contextual Learning for Disability (A-CLeD) learning model. A-CLeD model has a syntax that is; (1) Orientation, (2) Correlation, (3) Transformation, (4) Mediation and (5) Reflection. The result of content validity on this model shows the conclusion that this model is categorized well and can be used in physics learning for students with disabilities.

Keywords: Contextual Learning; student with dissabilities (blind student); Art of Contextual Learning for Disability (A-CLeD)

\section{PENDAHULUAN}

Pendidikan merupakan hak semua orang yang harus dipenuhi karena pendidikan merupakan proses sepanjang hayat untuk mengembangkan segenap potensi sebagai makhluk individu, makhluk sosial, dan makhluk tuhan. Hal 
ini sesuai dengan Deklarasi Universal Hak Asasi Manusia tahun 1948 dan Undang-Undang Dasar 1945 pasal 31 ayat 1 yang menyatakan bahwa setiap warga Negara mempunyai kesempatan sama memperoleh pendidikan. Tidak terkecuali siswa yang mempunyai kelainan fisik atau anak berkebutuhan khusus juga membutuhkan pendidikan untuk mengembangkan potensi yang dimilikinya secara optimal.

Anak berkebutuhan khusus merupakan anak yang membutuhkan pelayanan khusus karena adanya keterbatasan mental, fisik, maupun materi. Anak-anak ini membutuhkan layanan pendidikan yang sesuai dengan kebutuhan. Anak Berkebutuhan Khusus (ABK) terdiri dari dua kelompok, yaitu ABK temporer (sementara) dan ABK permanen (tetap). Adapun yang termasuk kategori ABK temporer adalah anak-anak jalanan (anjal), anak-anak korban bencana alam, dan anak-anak di daerah perbatasan dan di pulau terpencil. Sedangkan yang termasuk kategori ABK permanen adalah anak-anak difabel netra, tunarungu, tunadaksa, tunalaras, autis, Attention Dificiency and Hiperactivity Diorders(ADHD), anak berkesulitan belajar, anak berbakat dan sangat cerdas (Gifted), dan lain-lain (Efendi, 2006).

Keterbatasan yang dimiliki oleh ABK mengakibatkan informasi yang didapatkan juga sangat terbatas. Keterbatasan informasi yang didapatkan oleh anak berkebutuhan khusus lebih banyak dialami oleh anak difabel netra, karena kurang lebih $85 \%$ pengamatan dan informasi manusia dilaksanakan oleh mata. Kondisi tidak dapat melihat atau tidak dapat melihat dengan sempurna pada anak difabel netra mengakibatkan mereka kurang atau bahkan tidak memiliki pengalaman visual. Pemanfaatan indera penglihatan memudahkan seseorang melakukan penerimaan informasi dan membuat apersepsi terhadap peristiwa atau objek, terutama untuk membentuk suatu pengertian yang utuh (Munawir, 2011). Dalam proses pembelajaran fisika dibutuhkan indera penglihatan untuk memahami konsep dan teori, karena fisika merupakan ilmu yang mempelajari fenomena alam yang dimana peserta didik harus dapat memaknai setiap gejala dengan menggunakan pengamatan.

Guru fisika yang mengajar di sekolah luar biasa ataupun sekolah inklusi memiliki tantangan yang lebih besar dibandingkan guru di sekolah umum, karena keterbatasan yang dimiliki oleh peserta didiknya membuat guru harus ekstra kreatif dalam mengelola pembelajaran (Salim, 2010). Apabila pada peserta didik normal lebih mudah untuk memilih, meggunakan, dan mengembangkan strategi pembelajaran, berbeda dengan guru yang mengajar peserta didik difabel netra. Kecenderungan peserta didik difabel netra menggantikan indra pengelihatan dengan indra pendengaran sebagai salah satu saluran utama penerima informasi dari luar mengakibatkan pembentukan konsep hanya berdasarkan lisan. Akibatnya ada kecenderungan untuk menggunakan kata tanpa tahu makna sebenarnya. Penguasaan konsep yang terbentuk pada akhirnya hanya berdasarkan pesrsepsi peserta didik itu sendiri yang diperoleh berdasarkan pengalaman dan pemahaman sederhana dari informasi yang ditangkap (Winarti, 2015).

Berdasarkan hasil observasi di beberapa sekolah inklusi, untuk mata pelajaran Sains/IPA menjadi sangat sulit dinarasikan bagi guru karena terkendala dengan fenomena dan gambar-gambar pada materi yang bersifat abstrak dan sulit dibayangkan. Kesulitan ini lah yang menjadi salah satu hambatan siswa difabel netra dalam memahami konsep fisika. Perlu adanya bantuan media yang mampu me konkretkan konsep yang abstrak pada materi fisika (Utami, Winarti, \& Purwanto, 2014). 
Penting pula kiranya sebagai seorang guru untuk mengelola pembelajaran menjadi bermakna dan menarik bagi siswa agar konsep tersampaikan dengan menggunakan berbagai strategi ataupun model pembelajaran yang menyesuaikan dengan keterbatasan yang dimiliki oleh siswa difabel netra. Berdasarkan latar belakang di atas, maka penelitian ini bertujuan untuk mengembangkan model pembelajaran kontekstual Sains untuk peserta didik difabel netra.

\section{METODE}

Penelitian ini merupakan penelitian pengembangan (Research and Development). Penelitian pengembangan atau Research and Development (R \& D) adalah metode penelitian yang digunakan untuk menghasilkan produk tertentu, dan menguji keefektifan produk tersebut (Gall, Meredith Damien Borg, Walter R. Gall, 1996). Prosedur pengembangan yang digunakan dalam penelitian ini menggunakan langkah yang diadaptasi. Langkah-langkah penggunaan metode Research and Development (R \& D) menurut Borg \& Gall dapat disajikan sebagai berikut (Gall, Meredith Damien Borg, Walter R. Gall, 1996):

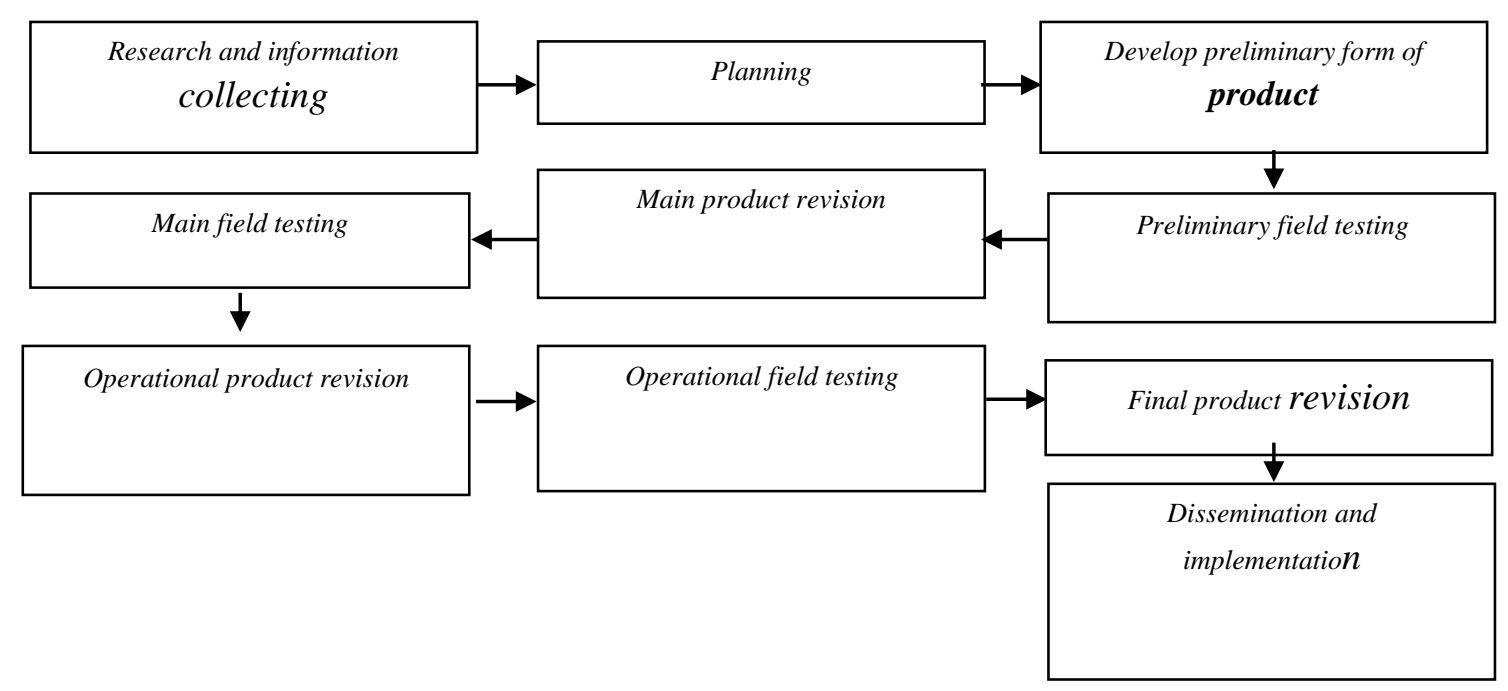

Gambar 1. Langkah-Langkah Metode R \& D

Untuk fase analisis kebutuhan yang dilakukan adalah dengan mencari informasi dari sekolah-sekolah inklusi, guru fisika dan ABK. Adapun sampel pada penelitian ini adalah 3 Sekolah inklusi dan 2 Sekolah Luar Biasa tipe A yang ada di Yogyakarta. Teknik pengumpulan data yakni dengan teknik non tes dengan wawancara, observasi dan angket. Adapun instrumen yang digunakan dalam penelitian ini adalah berupa pedoman wawancara, lembar observasi pembelajaran fisika dan lembar angket.
Untuk mengetahui kelayakan dari model yang dikembangkan maka akan dilakukan beberapa uji yakni validitas isi (content validity) dan uji implementasi dari model yang telah dikembangkan. Validitas ini bertujuan untuk mengetahui apakah produk yang dikembangkan sudah sesuai dengan tujuan (Allen \& Yen, 1979). Validitas isi dari model pembelajaran yang dikembangkan dalam penelitian ini dilakukan oleh 7 ahli. Sebuah instrumen dapat dikatakan memiliki validitas yang tinggi apabila mampu mengukur apa yang hendak diukur dan yang menjadi tujuan yang 
akan dicapai (Arikunto, 2013; Budiyono, 2015). Adapun ahli yang menilai produk yang dikembangkan adalah ahli fisika, ahli pendidikan, ahli inklusi dan guru sebagai pelaksana.

Setelah mendapatkan nilai valid yang berasal dari expert judgment kemudian akan dianalisis dengan $C V R$ dengan menggunakan persamaan formula Aiken, dengan persamaan yakni sebagai berikut:

$$
V=\frac{S}{[n *(c-1)]}
$$

(Sumber: (Aiken, 1985))

Adapun untuk menentukan nilai s adalah dengan menggunakan

$$
S=\Sigma n_{i}\left(r-l_{0}\right)
$$

V-aiken seperti persamaan di atas menunjukkan indeks validitas model pembelajaran yang dikembangkan. Validitas menggunakan $\mathrm{v}$ aiken ini hanya dilakukan untuk menentukan nilai validitas isi. V aiken dipengaruhi oleh beberapa faktor diantaranya banyaknya Penilai (raters) $n_{i}$, banyaknya kategori kriteria yang dinilai $c$, kriteria ke 1 yang dinilai $r$, dan kategori terendah dari instrumen $l_{0}$.

Tahap selanjutnya adalah merevisi berdasarkan masukan validator, untuk kemudian melakukan uji imlementasi dari model pembelajaran yang telah dikembangkan. Uji implementasi ini dilakukan untuk mengetahui apakah dalam implementasinya model pembelajaran ini dapat digunakan.

\section{HASIL DAN PEMBAHASAN}

Model pembelajaran adalah model yang digunakan oleh seorang guru untuk menyampaikan materi yang diajarkan kepada peserta didik. Model pembelajaran kontekstual merupakan suatu model pembelajaran holistik yang bertujuan untuk mengajarkan peserta didik dalam memahami materi dengan mengaitkan dengan konteks kehidupan nyata, sehingga peserta didik memperoleh pengetahuan dan keterampilan yang dapat diaplikasikan dan ditransfer dari suatu konteks permasalahan yang ke permasalahan lainnya. Berdasarkan penelitian (Nurcahyanto, 2015) model kontekstual merupakan salah satu model pembelajaran yang dapat mengaktifkan siswa dan memberikan pembelajaran yang berkaitan erat dalam kehidupan sehari-hari. Dalam pembelajaran kontekstual guru bukan lagi seorang yang paling tahu, guru layak utuk mendengarkan siswanya (Nurhadi, 2004). Berdasarkan kedua peryataan tersebut menunjukkan bahwa esensi dari model pembelajaran kontekstual adalah sebuah cara mengaktifkan peserta didik dalam pembelajaran dengan membawa pikiran mereka memahami onsep berdasarkan kejadian sehari-hari atau bahkan apa yang ada di lingkungan sekitar mereka. Pemahaman peserta didik tentang konsep fisika banyak dipengaruhi oleh pengalaman pribadi yang ditemui dalam kehidupan sehari-hari, dimana pengetahuan berdasarkan pengalaman itu pada akhirnya akan membentuk konsepsi peserta didik. Kesulitan sebagian besar peserta didik adalah mengemukakan alasan yang mendasari fenomena. Peserta didik menjawab hanya berdasarkan naluri saja, dimana sebenarnya jawaban tersebut logis tetapi belum sesuai dengan konsep yang benar. Hal ini sejalan pula dengan temuan penelitian yang dilakukan oleh (Zoller \& Tsaparlis, 1997); yang menyatakan bahwa bahwa kegagalan peserta didik adalah dalam membangun konsep tentang kerangka kerja logis dari suatu gejala fisika. Selain itu kelemahan lain yang dialami peserta didik adalah belum mampu menghubungkan gejala dengan konsep yang relevan sering menghasilkan konsepsi peserta didik yang tidak konsisten dengan konsep 
ilmiah (scientific ideas) bahkan cenderung akan membentuk alternatif konsepsi bahkan miskonsepsi.

Data hasil observasi, wawancara, dan angket menunjukan bahwa pembelajaran untuk anak difabel netra menggunakan prinsip pengalaman konkrit, penyatuan antar konsep, dan belajar sambil melakukan. Hasil tersebut sesuai dengan prinsip-prinsip pembelajaran difabel netra temuan ini sejalan pula dengan hasil penelitian (Garnida, 2015). Berdasarkan data tersebut dapat dirumuskan model pembelajaran sains kontekstual yaitu Model pembelajaran Art of Contextual Learning for Disability (A-CLeD). Model A-CLeD ini memiliki sintak yaitu; (1) Orientasi, (2) Korelasi, (3) Transformasi, (4) Mediasi dan (5) Refleksi. Berdasarkan berbagai evaluasi maka diperoleh sintak model pembelajaran kontekstual untuk peserta didik difable netra adalah seperti terlihat pada gambar 2 .

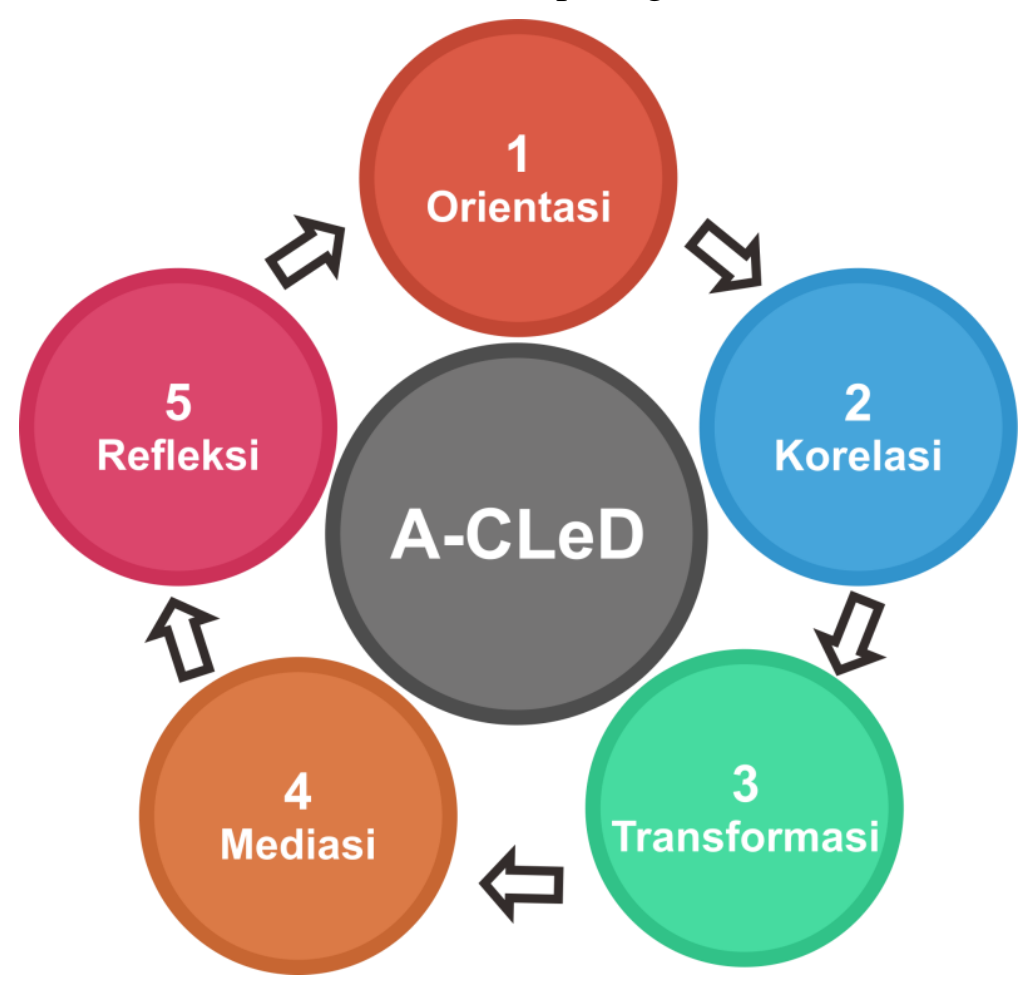

Gambar 2. Sintaks Model Art of Contextual Learning for Disability (A-CLeD)

Adapun fase model pembelajaran yang dikembangkan dapat dijelaskan lebih lanjut seperti di bawah ini yakni:

1. Fase Orientasi

Fase pertama dari model pembelajaran A-CLeD merupakan fase pembuka yang menekankan pada fase pembelajaran yang lebih kepada proses guru memberikan kasus-kasus autentik yang membangkitkan rasa ingin tahu peserta didik. Fase Orientasi adalah fase untuk membina suasana pembelajaran yang responsif. fase ini bertujuan untuk menyiapkan peserta didik secara psikis dan fisik untuk mengikuti proses pembelajaran. Guru merangsang dan mengajak peserta didik untuk berpikir memecahkan masalah dengan mengajukan pertanyaan-pertanyaan materi pembelajaran yang dikaitkan dengan pengalaman dan kehidupan nyata sehari-hari peserta didik. Pada fase orientasi dapat mengembangkan sikap ingin tahu peserta didik yang 
dapat dilakukan dengan cara berdiskusi dan tanya jawab mengenai materi yang disampaikan.

Fase orientasi merupakan fase yang sangat penting untuk dijadikan fase awal dari model pembelajaran A-CLeD karena, peserta didik inklusi terutama difabel netra memiliki kesulitan dalam pembentukan konsep terhadap pengalaman konkret dan fungsional dalam kehidupan sehari-hari. Melalui fase orientasi ini peserta didik mampu mengkongkretkan pembentukan konsep pembelajaran fisika dengan sebuah pertanyaan yang dikaitkna dengan pengalaman dari lingkungan alam dalam kehidupan sehari-hari sehingga dapat membangkitkan rasa ingin tahu peserta didik. Keberhasilan dari fase orientasi ini sangat tergantung pada kemampuan peserta didik untuk beraktivitas menggunakan kemampuannya dalam memecahkan masalah, tanpa kemauan dan kemampuan itu tak mungkin proses pembelajaran akan berjalan dengan lancar.

\section{Fase Korelasi}

Fase korelasi adalah fase menghubungkan materi pelajaran dengan peserta didik atau dengan hal-hal lain yang memungkinkan peserta didik dapat menangkap keterkaitannya dalam struktur pengetahuan yang telah dimilikinya. fase korelasi dilakukan untuk memeberikan makna pada materi pelajaran, baik makna untuk memperbaiki struktur pengetahuan yang dimiliki peserta didik. Menurut (Hosnan, 2016) dengan memberikan pembelajaran bermakna dapat meningkatkan kualitas kemampuan berfikir dan motorik peserta didik

Fase korelasi yang diterapkan untuk peserta didik difabel netra dapat dilakukan pembelajaran dengan memanfaatkan dirinya sendiri dan alat bantu yang berada dilingkungan sekitar sebagai media pembelajaran. Pada fase korelasi pada model A-CLeD guru berperan sebagai fasilitator.

Langkah memungkinkan untuk dilakukan adalah dengan mengajak peserta didik untuk mengeksplorasi lingkungan alam dalam kehidupan sehari-hari yang berkaitan dengan materi yang dipelajari. Jika materi berupa fakta, konsep, dan teori yang tidak dapat diwujudkan dalam konkret guru menyampaikan materi pembelajaran dengan memanfaatkan komunikasi verbalis kontekstual dengan memanfaatkan pengetahuan dan lingkungan sekitar peserta didik. Fase ini menggunakan alam sebagai objek laboratorium dalam pembelajaran kontekstual sains.

3. Transformasi

Fase ketiga dalam pembelajaran ini mengadopsi dari tahap ketiga pengembangan collaboratife learning. Dalam mengembangkan collaboratife learning salah satu tahap yang dilalui yaitu transformasi. Dari perbedaan kemampuan yang dimiliki oleh masing-masing peserta didik dapat saling bertukar pikiran dalam mendiskusikan materi untuk menemukan sebuah materi, fakta, dan konsep yang mudah dipahami oleh peserta didik. Dengan begitu peserta didik yang semula memiliki prestasi rendah, lama kelamaan akan menaikkan prestasinya karena adanya proses transformasi dari siswa yang memiliki prestasi tinggi kepada siswa yang prestasi rendah.

Fase transformasi pada model A-CLeD diharapkan terjadinya proses perubahan kerangka berfikir siswa terhadap hasil dari korelasi yang diberikan oleh guru. Fase ini 
merujuk pada pertukaran kemampuan peserta didik dengan teman-temannya yang mungkin salah satu dari mereka sudah memahami konsep terlebih dahulu dibandingkan dengan yang lain. Dalam prakteknya ternyata dengan pertanyaan pancingan yang sama ternyata tidak semua peserta didik difable netra memiliki persepsi yang sama tentang konsep yang dituju. Dengan adanya transformasi dan pertukaran pikiran ini membuat mereka terpacu untuk mengembangkan lagi kemampuan berpikirnya, sehingga memiliki persamaan persepsi terhadap suatu konsep. Perlu menjadi catatan guru pada fase ini bahwa pengungkapan defenisi (bahasa komunikasi) peserta didik difabel netra boleh saja berbeda tetapi makna dan persepsi mereka harus sama tentang suatu konsep.

\section{Mediasi}

Fase mediasi pada model ACLeD dapat dilakukan dengan mempererat komunikasi dan rasa kekeluargaan dengan peserta didik, fase ini mudah dilakukan meskipun dengan media pembelajaran yang terbatas. Kegitan pembelajaran peserta didik dapat dilakukan dengan menggali informasi mengenai pemahaman materi siswa dengan melakukan sebuah presentasi untuk mengetahui tingkat pemahaman materi, dan membuka kesempatan secara luas kepada siswa untuk mengajukan pertanyaan secara mandiri.

Hal yang menjadi dasar adanya fase mediasi ini adalah bahwa belajar bersama peserta didik yang berkebutuhan khusus itu harus tetap menggunakan pendekatan individu. Hal ini bertujuan agar mereka merasa termotivasi dan dihargai untuk belajar tanpa menghilangkan esensi dari penyampaian konsep. Fase mediasi ini diharapkan peserta didik dapat mengungkapkan hasil pembelajaran yang diperoleh dari fase korelasi dan transformasi.

\section{Refleksi}

Fase refleksi pada model ACLeD mengadopsi dari fase-fase penerapan pembelajaran CTL (Contextual teaching and learning). Refleksi adalah cara berfikir tentang baru apa yang dipelajari atau berfikir kebelakang tentang apa-apa yang sudah dilakukan masa lalu.Pada fase terakhir ini aktifitas yang dilakukan peserta didik adalah memberikan umpan balik (feedback) terhadap seluruh proses pembelajaran dengan mengembangkan kemampuan analisis dan mengevaluasi dalam self regulated learning, yaitu pengetahuan tentang strategi paling efektif yang akan digunakan untuk belajar, bagaimana peserta didik menggunakannya dan kapan akan digunakan. Refleksi bukan saja kegiatan yang dilakukan peserta didik tetapi tentunnya juga dilakukan oleh guru. Guru dapat memberikan feedback dengan memberikan koreksi dan penguatan terhadap apa yang telah dilakukan peserta didik dalam menyelesaikan masalah ataupun menyampaikan pendapat sehingga ketika ada kekeliruan dapat segera dibenahi agar peserta didik segera memahami konsep. Menurut (Arends, 2013) Feedback yang dilakukan guru dalam pembelajarann harus diberikan secara spesifik dan sesegera mungkin supaya diperoleh pengetahuan dengan baik pada diri peserta didik.

Refleksi dilakukan pada akhir pembelajaran, guru dapat menyisakan waktu untuk melakukan refleksi. Kegiatan refleksi dapat berupa membimbing siswa merangkum atau menyimpulkan 
semua materi yang telah dipelajari dengan menanyakan ulang tentang materi yang telah disampaikan. Pada tahap refleksi juga dpat digunakan untuk mengetahui sejauh mana pemahaman siswa tentang materi yang telah dipelajari dpat dilakukan dengan memberikan tes baik secara lisan maupun tertulis. Adapun yang dilakukan pada tahap refleksi ini adalah:

1. Bersama-sama peserta didik melakukan riview terhadap hasil penyelesaian permasalahan dan materi

2. Membimbing peserta didik untuk membuat kesimpulan berdasarkan hasil diskusi pada tahap transformasi.

Hasil validasi terhadap model ini menunjukkan kesimpulan bahwa model ini berkategori baik dan dapat digunakan dalam pembelajaran fisika untuk peserta didik difabel netra.

\section{SIMPULAN}

Berdasarkan hasil penelitian dapat disimpulkan bahwa telah berhasil dikembangkan model pembelajaran sains kontekstual untuk peserta didik difabel netra dengan nama Model pembelajaran Art of Contextual Learning for Disability (A-CLeD). Model A-CLeD ini memiliki sintak yaitu; (1) Orientasi, (2) Korelasi, (3) Transformasi, (4) Mediasi dan (5) Refleksi. Diharapkan dengan adanya model ini akan menambah dan memfasilitasi guru fisika (IPA) untuk mengajar di kelas inklusi ataupun mengajar untuk peserta didik difabel netra di sekolah.

\section{UCAPAN TERIMAKASIH}

Ucapan terimakasih kami sampaikan kepada Lemlit UIN Sunan Kalijaga yang telah mendanai penelitian ini dalam skema penelitian Rintisan Individu pada Program Penelitian APBN/BOPTN Tahun Anggaran 2017.

\section{DAFTAR PUSTAKA}

Aiken, L. R. (1985). Three Coefficients for Analyzing the Reliability and Validity of Ratings. Educational and Psychological Measurement, 45(1), 131-142. https://doi.org/10.1177/0013164485 451012

Allen, M. J., \& Yen, W. M. (1979). Introduction to Measurement Theory - Mary J. Allen, Wendy M. Yen Google Buku. Long Grove, Illinois: Waveland Press, Inc. Retrieved from https://books.google.co.id/books?hl= $\mathrm{id} \& \mathrm{lr}=\& \mathrm{id}=\mathrm{MNUpY}$ _csc6cC\&oi=fn $\mathrm{d} \& \mathrm{pg}=\mathrm{PR} 1 \& \mathrm{dq}=$ Introduction+to+M easurement+Theory\&ots=yoTqY1lZ Te\&sig=05oT4yILjuMhWJUne 5cS PkqRnrw\&redir_esc $=y \# v=$ onepage $\& q=$ Introduction to Measurement Theory\& $\mathrm{f}=$ false

Arends, R. . (2013). Learning to Teach: Belajar untuk Mengajar. Jakarta: Salemba Humanika.

Arikunto, S. (2013). Dasar-dasar Evaluasi Pandidikan. Jakarta: Bumi Aksara.

Budiyono. (2015). Pengantar Teori Pengukuran Pendidikan. Surakarta: Universitas Sebelas Maret.

Efendi, M. (2006). Psikopedagogik Anak Berkelainan. Jakarta: Bumi Aksara.

Gall, Meredith Damien Borg, Walter R. Gall, J. P. (1996). Educational research: An introduction (6th ed.). NY: $\quad$ England: Longman Publishing.Longman Publishing. Retrieved from http://psycnet.apa.org/record/1996- 
97171-000

Garnida, D. (2015). Pengantar Pendidikan Inklusif. Bandung: Refika Aditama.

Hosnan, M. (2016). Pendekatan Saintifik dan Kontekstual dalam Pembelajaran Abad 21. Bandung: Ghalia Indonesia.

Munawir, Y. (2011). Guru difabel netra Dewasa dan Pembina Karir. Jakarta: Departemen guru dan Kebudayaan Jendral guru Tinggi Proyek Pendidian Tenaga Akademik.

Nurcahyanto, G. (2015). Pembelajaran Kimia Melalui Pendekatan Ctl (Contextual Teaching and Learning ) Melalui Metode Proyek Dan Metode Inquiry Terbimbing Ditinjau Dari Kreativitas Siswa. Prosiding Seminar Nasional Pendidikan Sains, (November), 2015-495.

Nurhadi. (2004). Pembelajaran Kontekstual (Contextual Teaching and Learning) dan Penerapannya dalam KBK. Malang: Universitas Negeri Malang.

Salim, A. (2010). Pengembangan Model Modifikasi Kurikulum Sekolah Inklusif Berbasis Kebutuhan Individu Peserta Didik. Jurnal Pendidikan Dan Kebudayaan, 16(Edisi Khusus I), 21-34.

Utami, R., Winarti, W., \& Purwanto, J. (2014). Rancang Bangun Perangkat Eksperimen Hukum Archimedes untuk MTs LB/A Yaketunis Kelas VIII. INKLUSI, I(1), 57. https://doi.org/10.14421/ijds.010104

Winarti, W. (2015). Tantangan pendidikan inklusi dalam menghadapi masyrakat ekonomi asean. In Seminar Nasional Pendidikan Fisika. Madiun: IKIP
PGRI Madiun. Retrieved from http://ejournal.unipma.ac.id/index.php/snpf/ article/view/983/873

Zoller, U., \& Tsaparlis, G. (1997). Higher and lower-order cognitive skills: The case of chemistry. Research in Science Education, 27(1), 117-130. https://doi.org/10.1007/BF02463036 